Article

\title{
Food as Commons or Commodity? Exploring the Links between Normative Valuations and Agency in Food Transition
}

\author{
José Luis Vivero-Pol ${ }^{1,2}$ \\ 1 Biodiversity Governance Research Unit (BIOGOV), Center for the Philosophy of Law (CPDR), \\ Universite Catholique of Louvain, Louvain-la-Neuve 1348, Belgium; \\ jose-luis.viveropol@uclouvain.be; Tel.: +32-10-474646 \\ 2 Earth and Life Institute, Faculty of Biological, Agricultural and Environmental Engineering, \\ Universite Catholique of Louvain, Louvain-la-Neuve 1348, Belgium
}

Academic Editor: Marc A. Rosen

Received: 21 November 2016; Accepted: 10 March 2017; Published: 17 March 2017

\begin{abstract}
The food system, the most important driver of planetary transformation, is broken. Therefore, seeking a sustainable and socially-fair transition pathway out of this crisis becomes an issue of utmost priority. The consideration of food as a commodity, a social construct that played a central role in this crisis, remains the uncontested narrative to lead the different transition pathways, which seems rather contradictory. By exploring the normative values on food, this paper seeks to understand how relevant is the hegemonic narrative of food as commodity and its alternative of food as commons to determine transition trajectories and food policy beliefs. Applying the multi-level perspective framework and developing the ill-studied agency in transition, this research enquired food-related professionals that belong to an online community of practice $(N=95)$ to check whether the valuation of food is relevant to explain personal stances in transition. Results suggest that the view of food as commodity is positively correlated with a gradually-reforming attitude, whereas food as commons is positively correlated with the counter-hegemonic transformers, regardless of the self-defined position in the transition landscape (regime or niches). At a personal level, there are multiple loci of resistance with counter-hegemonic attitudes in varied institutions of the regime and the innovative niches, many of them holding this discourse of food as commons. Conversely, alter-hegemonic attitudes are not positively correlated with the alternative discourse, and they may inadvertently or purportedly reinforce the neoliberal narrative. Food as commons seems to be a relevant framework that could enrich the multiple transformative constituencies that challenge the industrial food system and therefore facilitate the convergence of movements that reject the commodification of food.
\end{abstract}

Keywords: food valuation; food as commons; food as commodity; transition theory; narratives of transition; agency in transition; transformative agency; counter-hegemonic attitudes; gradual reformers

\section{Introduction}

"Food is not a commodity". This statement seems to be increasingly concealing agreement from very different constituencies and political leaders, starting from Pope Francisco's headlines-catching encyclical text "Laudato si" [1] with noteworthy thoughts delivered in recent speeches at FAO (2014) and WFP (2016), followed by Via Campesina's representatives in hundreds of conferences [2], the U.S. President Clinton's statement delivered in 2008 ("Food is not a commodity like others... it is crazy of us to think we can develop a lot of these countries by treating food like it was a colour television set" (quoted by Philip McMichael [3])) and ending with numerous researchers from different disciplines [4,5]. Pope Francis, voicing a renewed Catholic Social Teaching (According to some authors [6], former 
Catholic doctrine of property was influenced by the classical liberal tradition founded by John Locke [7]. However, the revision of this doctrine brought the principle of the universal destination of the world's goods having precedence over the right to private property (Laudato $\mathrm{Si}$, para 93) [1]), said during his Rome speeches that "it is painful to see the struggle against hunger and malnutrition is hindered by the primacy of profit, which have reduced foodstuffs to a commodity like any other, subject to speculation, also of a financial nature" and that "we have made the fruits of the Earth-a gift to humanity-commodities for a few, thus engendering exclusion", whereas "we are no longer able to see the just value of food, which goes far beyond mere economic parameters". Nowadays, however, the industrial food system continues treating food as a commodity and not as a sustainer of life [8] (p. 11), being its value no longer based on its many dimensions that bring us security and health, but on the tradable features that can be valued and priced in the market. Value and price are thus mixed up, superseding non-economic dimensions, such as being the essential fuel for the human body or its relevance for individuals' and societies' culture. Accepting that the dominant industrial food system is in a deep crisis [9-11], recognizing that multiple stakeholders are looking for different transition pathways out of this crisis [12] and based on the idea that the commodification of food is the major structural cause of this crisis [13], this paper explores the different dimensions of food relevant to humans, how food-related professionals value these dimensions and what valuations are more often found in different loci of the transitional food system, thus contributing to the understanding of the role of agency in steering transition pathways in the global food system.

In this paper, the contemporary industrial food system is identified as the dominant regime, its primary narrative of "food as a commodity" being the hegemonic discourse regarding the valuation of food, after Gramsci's concept of hegemony of ideas [14], and the default political attitudes are interpreted as follows: gradual reforming as the preferred stance by the actors that conform to the regime $[15,16]$ and transformative innovations to be the most prevalent within those respondents working in niches $[17,18]$.

The paper is organized as follows: Section 2 explains the symptoms of the deep crisis that affect the dominant regime of the global food system, here termed as the industrial food system. Those symptoms are then linked in Section 3 to the absolute commodification of food, a social construct identified as the underlying cause that fuels this crisis. Section 4 provides an introduction to the multi-level perspective of socio-technical transitions and explains the meanings of agency in transition and agency in food systems. Section 5 moves beyond the theoretical approaches to agency to explain the three proxy indicators used to understand agency in this paper, namely the transition locus, the political attitudes and the valuation of food, as well as the different typologies created. Section 6 describes the methodology, justifies the appropriateness of the global sample (understood as a community of practice with web-based connections) and describes the interviewees. Results are presented in detail in Section 7, firstly with descriptive results of the agency variables and then detailing the correlation and regression analyses. Section 8 incorporates the discussion of the main results and the implications of the different valuations of food dimensions and regime-niches' dialectical relationships. The paper concludes in Section 9 with the recognition that the normative way we value food, either as a commons or a commodity, shapes our attitude in the transition scenario. Finally, there is a call to food-related scholars from different disciplines to critically engage with the unfolding of the alternative narrative of "food as a commons" where the multiple dimensions of food, other than the economic ones, are equally and properly valued. Due to space restrictions, Supplementary Materials for Section 5 (agency variables), Section 6 (methodology) and Section 7 (results) and three appendixes are included at the end of the article.

\section{The Food System Is Broken}

The global food system is in crisis - when referring to global, the author is mostly referring to the industrial food system that conforms the dominant regime- and therefore, multiple tensions are pushing for exit alternatives to this crisis stage (called transition pathways in this research). The current economic model of endless growth is pushing us inexorably towards the limits of natural resources 
and planetary life support systems, limits that we have already surpassed for four out of nine global thresholds [19]. Human beings are becoming the main cause of planetary transformation, leading us to a new era that has been termed as the Anthropocene by geologists [20] or the Capitalocene by sociologists [21]. Within the human-made set of activities that are drastically transforming Earth, food-production leads the way [22]. Agriculture, the economic activity forty percent of the world's population relies on for their livelihood [23], is the main driver of Earth's destruction. Although the need for a drastic shift has become commonly accepted by many scholars from different disciplines [10,24], the transition pathway to follow is still subject to dispute.

Globally speaking, we have a troublesome relationship with food, as more than half the world eats in ways that damage their health [25]. Obesity and undernutrition affect an estimated 2.3 billion people globally [26], and we have still 795 million undernourished people in the world [27]. The ironic paradoxes of the globalized industrial food system are that $70 \%$ of hungry people are themselves food producers [28]; food kills people [29,30]; food is increasingly not for humans (a great share is diverted to biofuel production and livestock feeding [31]); and one third of global food production ends up in the garbage every year, enough to feed 600 million hungry people [32]. The side-effects of the industrial food system can be summarized in high water waste [33]; the impoverishment of the nutritious properties of some foods [34]; an overemphasis on the production of empty and cheap calories that increase obesity; soil degradation and biodiversity loss amongst others.

Due to this crisis, multiple voices call for a paradigm shift, although the values, narratives, economic and moral foundations of that new aspirational and inspirational paradigm are not yet elucidated. There are several narratives of transition on where do we want to go and how are we going there. Nevertheless, it is worth mentioning that, despite this call for "a paradigm shift", major analyses on flaws in the global food system and the very existence of hunger do not question the very nature of food as a private good [25,35-37]. Yet, there is a growing consensus in certain areas of academic research, as well as within the transformational social movements that consider the absolute commodification of food as one of the faulty rationales that are leading us to this crisis. This commodification obscures other non-economic dimensions that are quite important for individuals and society as a whole.

\section{Commodification as a Major Cause of This Crisis}

The conversion of goods and activities into commodities has been a dominant force transforming all societies since at least the mid-nineteenth century [38,39], a process that has led to today's dominant industrial system that fully controls international food trade [28] and increasingly exerts a monopoly over agricultural inputs, such as seeds [40], water [41], land [42], agro-chemicals or machinery [43], while failing to feed the world's population in a sustainable manner. Considering food as a commodity refers to unbranded or undifferentiated items from multiple producers, such as staple grain, beef meat or fresh vegetables that are largely valued by its price in the market. What makes food a commodity is the reduction of its multiple values and dimensions to that of market price, being profit maximization the only driving ethos that justifies the market-driven allocation of such an essential for human survival [44]. Profit-seeking explains why food is wasted and food is actually not meant to feed people. The industrial food system basically operates to accumulate and underprice highly caloric food resources and maximize the profit of enterprises instead of maximizing the nutrition and health benefits of food to all $[45,46]$. As a commodity, international food trade that only accounts for $23 \%$ of global food production [47] is dominated by a few transnational companies [45].

The social construct of food as a commodity denies its non-economic attributes in favor of its tradable features, namely durability, external beauty and the standardization of naturally-diverse food products, leading to a neglect of the nutrition-related properties of food, alongside with an emphasis on cheap calories. These cheap calories are low-cost sources of dietary energy, such as refined grains, added sugars and fats, which, inexpensive and tasty, together with salt, form the basis of ultra-processed industrial food; the more nutrient-dense lean meats, fish, fresh vegetables and fruit are generally more costly because they are not so highly subsidized [48]. They not only come at great cost to the 
environment (the sustainability issue), but also human health (the obesity issue) and social relations (eating alone is mounting). The "low cost" industrial food system that delivers cheap food -food is cheap in just one specific sense: more calories produced with less average labor-time in the globalized commodity chain system [49] — to a large proportion of the world's population is based on capitalism's greatest strength, namely its capacity to create and appropriate cheap natures, these being labor, food, energy or raw materials [50].

Under capitalism, the value in use (feeding people) is highly dissociated from its value in exchange (price in the market) [51], giving primacy to the latter over the former [52]. Food as a pure commodity can be speculated on by investors - speculation on food commodity futures represents the most extreme effect of the commodification of food [10] with no recognition of its dimension as an essential element of life-modified genetically and patented by corporations, or diverted from human consumption just to maximize profit, the latest twist on this being the substitutionism of food commodities [53], whereby tropical products (sugar cane, palm oil, etc.) are replaced by agro-industrial and pharmaceutical by-products (for high fructose corn syrup, margarine, etc.). In the dominant narrative of the industrial food system, food is valued as a commodity and a tool of power, while humans are merely seen as consumers whose only way of asserting their autonomy is via the ultimately pointless choice between food brands [54]. Food agency is restricted to the "sovereign act of consuming", which leads to a loss of agency to govern a vital resource.

To many, this reduction of the food dimensions to one of a commodity explains the roots of the failure of the global food system [55,56]. Moreover, market rules not only put prices to goods, but in doing so, markets corrupt their original nature [57]. The commodification of food crowds out non-market values and the idea of food as something worth caring about, such as recipes associated with some types of food, the conviviality of cooking or eating together, the local names of forgotten varieties and dishes or the traditional moral economy of food production and distribution, materialized in the ancient and now proscribed practices of gleaning and famine thefts. Those food-related qualities can neither be valued nor regulated by the market, which is why the treatment of food as simple commodity results often in social upheaval [16].

\section{Theoretical Premises of "Agency in Food Transitions"}

The Multi-Level Perspective (MLP) on sustainable transitions is a theoretical framework that explains the transition pathways towards an enhanced sustainability between different stages of socio-economic systems [58,59]. As the global food system is transiting from a multiple crises stage towards an aspirational sustainable one, this framework is judged as appropriate to be used here. Key elements in this theory are the innovative niches, the dominant regime and the broader landscape, as well as the interactions between these three elements [60]. Niche-innovations may gradually develop through learning processes, the expansion of social networks and supporting constituencies, as well as the articulation of appealing visions and expectations [61], in what is termed as the narrative. Socio-technical transitions may take different pathways, and they involve contested processes in numerous loci, multiple social groups, diverging narratives of transition, clashing ideologies and vested interests, many of which are outside the immediate control of policymakers.

However, the transition theory, as originally formulated, seems to be insufficient to explain the forces that enable the fittest niches to become relevant competitors of the mainstream regime and how some of those niches may co-exist, confront or replace the mainstream all along the transition pathway. A fine-tuned analysis of driving agents in the socio-technical regimes has to be conducted so as to understand the main role of agency, exemplified here as actual people in existing institutions holding specific values or defending a particular narrative, the power balance of different agents and the hegemonic paradigms.

Human agency in transition drinks obviously from the theory of agency in development and the theoretical approaches to multi-dimensional poverty undertaken by Amartya Sen, who defined agency as "an assessment of what a person can do in line with his or her conception of the good" [62]. 
People who enjoy high levels of agency are engaged in actions that are congruent with their values [63] or their own interests [64] (p. 15); human agency, either individual or collective, is fundamentally cultural, and the role of narratives is central in its underpinning [65].

Along those lines, agency in transition can be understood as motivations, beliefs and values of individual agents steering or influencing the transition pathways [66], and its conceptualization in transition theory has not been properly addressed, being a recurrent subject of critique by authors that analyzed the politics of transitions [67,68]. Actually, although it is the agency of actors that drives transitions [69], agency-sensitive analysis of sustainable transitions has been very rare in the first period of the transition academic research. As a sort of defense, Geels responded that transition trajectories and alignments were always enacted by social groups (or in our particular research, a community of practice) [59].

In the last few years (and especially since the 2008 food crisis), the MLP framework has increasingly been used to understand transitions in the agricultural and food systems [70-73], transitions spurred by the generalized feeling that the 2008 crisis of international food prices was just a symptom of a broader and structural problem in the globalized industrial food system. As food production and consumption practices are essentially social, cultural, as well as biological [54], understanding "agency" beyond the socio-technical innovations, enabling legal frameworks and policies that frame transitions is pivotal to interpret the dynamics of change and the struggle between transition trajectories. Food is one of the structures of society [74] (p. 53); the desire for food is the most powerful driver of human agency [75]; and food has been associated with agency [76], power [77] and a means to contest the system [78]. Therefore, conflict and contestation are inherent to food systems because they involve the production, distribution and access of a vital resource for humans that greatly structures our societies and largely shapes our cultivated planet. Therefore, understanding transitions in the global food system cannot be fully undertaken without addressing "individual agency of food system actors", either in the form of the powerful agency of regime actors trying to protect their status and only accepting gradual reforming proposals or as transformational agency aimed to revolutionize the system, a position that can be materialized as counter-hegemonic constituencies (i.e., food sovereignty, agro-ecology) or alter-hegemonic ones (i.e., transition, de-growth, commons).

\section{Agency Variables Explained}

This research aims to elucidate the "individual agency in food systems in transition" that informs different scales and depths of change, has different views on production and consumption, takes inspiration from different academic disciplines, represents different views on policy and embodies different epistemological and normative assumptions. It is important to stress that we are analyzing human agency (people's values and narratives and political attitudes) and not institutional agency or mandates. Although the author recognizes the complexity and nuances of personal positions, food valuations and attitudes of transition cannot be encapsulated in two or three typologies (as presented below); this research is a first exploratory analysis of different food valuations, and this reductionism is necessary at this point to glimpse broad correlations. Further research and more samples will be required afterwards to test the results of this paper. To explore agency, this research uses three proxy variables based on where interviewees position themselves in the transition landscape, what political attitude they adopt and how they value food. The former two variables are explained in detail with extensive literature in Supplementary Materials whereas the valuation of food dimensions is discussed below. The three variables are briefly summarized as follows:

(a) The self-consideration of the position of the respondent's food-related activity in the food system transition landscape being either regime or niche, after the MLP theory.

(b) The political stance of the food-related activity the interviewee is involved with-vis à vis the (existing) food system-is defined here as reforming or transformative, being the latter split into alter-hegemonic and counter-hegemonic. Reformers advocate for incremental changes, adjustments and moderate shifts as long as the core features of the system remain untouched. 
Transformers seek a more profound and drastic change in structures, values and the balance of power. Alter-hegemonic works towards an incremental erosion of structures within interstices and edges, whereas counter-hegemonic promotes a complete up-rooting of the deep structures that preserve the status quo.

(c) The valuation of different food dimensions, primarily comparing economic and non-economic dimensions, enable us to classify the respondent's regard as valuing food as a commodity (mono-dimensional approach) or a commons (multi-dimensional approach). The conceptual framework of the multiple dimensions of food important for humans (see Figure 1) has been drafted by the author in previous papers $[79,80]$ and refined in the paragraphs below. The valuation of these dimensions corresponds to a perception of "food as a commodity", when the economic tradeable dimension prevails over the non-economic ones; or "food as a commons", when the different dimensions are equally and properly valued, and the tradeable dimensions does not obscure the non-economic ones.

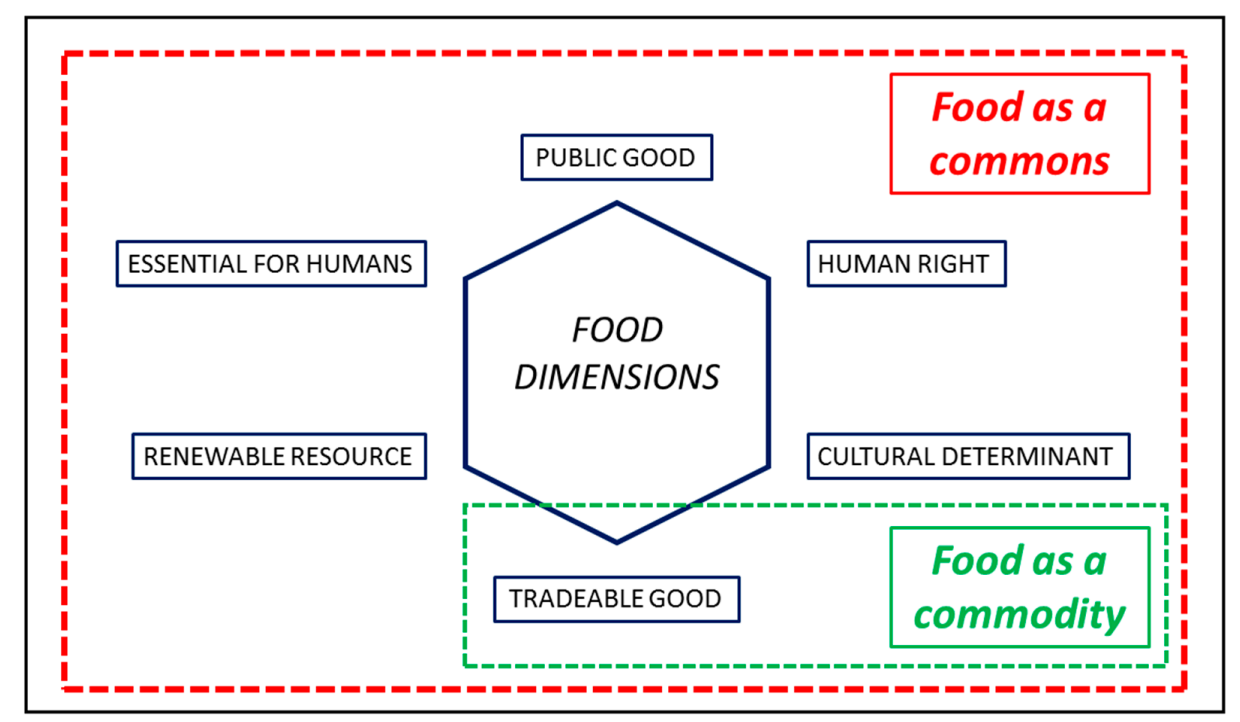

Figure 1. The six dimensions of food relevant to humans and explored in this research.

\subsection{The Multiple Dimensions of Food Important to Humans}

Food is one of the three essential resources humans require to keep their vital functions, along with water and air. Food is, first and foremost, a satisfier of the human need of subsistence [81] that impacts strongly our capabilities and agency [82]. Food as a resource, and eating as the act of satisfying that need, is an absolute or categorical need because it is determined by our biological requirements, which exerts particular demands on moral agents and public policies [83]. As an absolute need, it is neither substitutable nor negotiable, as it cannot be considered as a social construct. In that sense, an essential principle is applicable to absolute human needs: nobody's non-substitutable need may be sacrificed to the desires or lesser needs of any group of other people [84] (p. 24).

Along those lines, influential scholars considered the existence of "primary goods" from which the other goods are derived (Rawls's "merit goods" [85] or Polanyi's "livelihood of man" [86]), those goods deserving a special treatment in our society. A just society requires that all humans have the capability to live the lives they have reason to value [82], and in order to do so, it is unacceptable on normative grounds that every human cannot satisfy his/her food needs when we already grow enough food to feed adequately the current and the expected population $[27,87]$ and that food scarcity is artificially created through human-made enclosing mechanisms and political and institutional choices [88].

Being that vital need absolute and the same in all cultures and in all historical periods [89], access to adequate food has been re-constructed as a human right (a social construct that is context-specific) 
in the second half of the XX century [90]. In that sense, food is formally considered a binding human right recognized under international law. The right to food protects the rights of all human beings to feed themselves in dignity, either by producing their own food, by purchasing it or by receiving it from welfare systems, as enshrined in Article 25 of the Universal Declaration of Human Rights [91] and Article 11 of the International Covenant on Economic, Social and Cultural Rights [92]. Designating a good as a human right means under no jurisdiction and no circumstances may that good be denied to anybody [93] (p. 120).

It is worth mentioning that during the same period, a parallel social construction was also built up by economists around the public and private nature of goods, a classification based on just two features (excludability and rivalry) that posited that food was a private good and thus an appropriate candidate to be better allocated by market forces instead of public institutions [94]. However, those two features are nothing but another social construct, and society can modify the (non)-rivalry and (non)-excludability of goods that often become private or public as a result of deliberate policy choices [95]. In the case of food, the excludability of a good that is so essential to human beings shall be tempered by the compulsory fulfillment of a basic right to life if the specific moral grounds of any given society in any given point of time are so considered.

Additionally, none can deny the importance of food as a foundational pillar of culture and civilizations. Everything having to do with food, such as its collection, capture, cultivation, preparation and consumption, represents a cultural act [96]. In many countries, social life pivots around meals, and there are shared values about what is good food [97]. Not just society-wise, food is also central to our identity as individuals and as members of a society [98]. For centuries, food was cultivated in common and considered a mythological or sacred item, and fits production and distribution has been (and still is) thus governed by non-market rules, being in many cases produced, distributed and eaten in commons [99]. Food plays a key role in creating social bonds with relatives, friends and colleagues, since humans tend to eat together (commensality), thus reflecting the social relationships of individuals [100].

Although today, most foods are derived from cultivated plants and domesticated animals, a substantial part of the global human diet still comes from wild plants and animals. Natural ecosystems are an almost unlimited source of edible plants and animals, ranging from game and bush meat, fish and fowl, to vegetables, fungi or fruits [101]. In highly urbanized Europe, with a deep penetration of industrial modes of food production, wild food is still consumed by more than 100 million people and provided by more than 150 species [102]. The marine species represent another interesting case to portray. Fish stocks, especially those in international waters, are generally accepted as global commons [103], and the same assumption remains in place for fish stocks in coastal areas, although termed as national commons [104]. With regard to ownership of nature's resources, the controversy on who owns, governs or has entitlements over natural food resources has a long history, being a debate originally held by philosophers and rulers (i.e., Aristotle, Roman Emperors or feudal lords; see [105,106]), but since Locke, being largely dominated by economists $[107,108]$.

However, food dimensions do not stop here, as food is also a tradeable good since the origin of settled agricultural societies. As explained earlier, food trade has existed since the beginning of human settlements, but it was always tightly controlled by those in power (government) since food is a good like no other. Food exchanges, monetized or not, were done under strict public governance and always with the primary purpose of feeding people, since non-economic dimensions of food were also valued and protected. Profit maximization was not the only driving ethos of food production and distribution, but earning a living and feeding humanity. However, the commodification of food created an industry of selling food just for profit, not for feeding.

Finally, food has also a public dimension that has not been so far properly valued, a dimension that jointly with the others renders food as a commons and invalidates its treatment as a mono-dimensional commodity. We subscribe that the consideration of any given good as private or public is a result of "deliberate policy choices" made by any given society at any given period in history $[95,109]$ based on moral grounds, perceived needs, dominant paradigms, shared values and socially- and 
politically-derived agreements. Actually, public goods can be generated through collective choices (i.e., voting in a referendum to declare water a public good to be enshrined in the Constitution, such as the recent case in Slovenia) and be owned through private, public and collective proprietary regimes [110] with different proprietary rights [108]. Public goods, in the political sense, can be produced by governments because the market does not or because a society decides that all citizens should have access to them because their social or economic benefits are important or essential, regardless of the ability to pay. Food evidently qualifies as such. A regime that considers food as a public good would be governed in a polycentric manner by food citizens [111] that develop food democracies [112], which adequately value the different dimensions of food. Actually, the development of "food citizenship", in opposition to "food consumers", requires moving beyond food as a commodity [113].

\subsection{Multidimensional Food as a Commons}

There are multiple definitions of commons, being as diverse as the schools of thought that posit them. Economic, political, legal and historical scholars have all produced definitions on the commons. For the sake of this paper, commons are compounded by a resource and a governing community. The resources-tangible and intangible — can be accessed and used by the community that governs their management and steward their survival. The concept is applicable at the local, national and global level, if the community notion is extended to the population of the planet. The consideration of food as commons rests upon revalorizing the different food dimensions that are relevant to human beings, thereby reducing the importance of the tradable dimension that has rendered it a mere commodity. This multi-dimensionality endows this resource with the commons category. Food as a commons is compounded by a resource (any living material, either produced naturally or cultivated, that may be eaten by humans) and a governing community, which can be local (food buying groups), national (collecting licenses for wild mushrooms or game hunting) or international (i.e., the International Convention for the Conservation of Atlantic Tunas), and whose proprietary regimes may be private, public or collective, being the primary goal to secure that all members participate in the governance and the benefits of that resource. Every eater should have a saying in how the food resources are managed (an idea that has been termed as food democracy), and every eater should be guaranteed a fair and sufficient access to that resource, regardless of his/her purchasing power. The end-goal of a food commons system should not be profit maximization, but increased food access, building community and shortening the distance from field to table [114]. The food commons encompasses ancient and recent history (customary valuations of food in different civilizations, as well as modern and urban civic collective actions for food), a thriving alternative present (the myriad of alternative food networks that share, barter and exchange food by means of non-monetized mechanisms) and an innovative, utopian and just vision for the future [115].

Regarding the valuation of the six food dimensions, the assumption of this research is as follows:

(a) The recognition of these food dimensions is universal, whatever age, gender and culture (although food as a human right is contested in some countries), but individuals differ in the weight and priority assigned to each dimension.

(b) Food dimensions matter to humans as they shape our relationship to food and food-producing systems.

(c) The valuation of food dimensions triggers human agency and the political stance vis à vis the food system, being an important factor in separating a food consumer from a food citizen.

(d) Societies value food dimensions differently in specific historical and geographical contexts

(e) Food dimensions connect multiple elements and drivers that interplay in the food systems, as well as other issues, such as biodiversity, climate change, gender and poverty. 


\section{Materials and Methodology}

Describing the Sample: Food System Professionals with Social Network Profiles as Agents of Change

The research hypothesis is that the way people value food is correlated with the political stance vis à vis the existing food system adopted by individuals. In order to test that hypothesis, the author decided to ask food-related professionals working in different institutions, countries and socio-economic circumstances so as to pulse the dominant narratives of transition that can be found in the landscape (using a terminology borrowed from the transition theory). This case study gathers different actors having in common a strong interest in food, an influential role in the local, national or international food systems and being active in social networks (they all have a Twitter ${ }^{\mathrm{TM}}$ profile where they tweet on food-related issues). The interviewees are thus considered as agents of change and members of a community of practice. A community of practice, after Lave and Wenger [116], is a group of people who shares a craft or a profession (food issues here), and they share experiences over time, common sense-making and self-regarding, either physically or virtually [117]. It is through the process of sharing information and experiences that the members of this community learn from each other and develop common discourses and shared values. Therefore, the food-related professionals active in web-based social networks are part of a broad constituency that is trying to change the global food system from within. They all have agency to steer the transition of the global food system, and they choose food as a means of forging social and economic justice [118]. A questionnaire was sent to them (see Supplementary Materials for the sampling methodology and the questionnaire).

The sample, in numerical terms, consists of 38 food activists in national or international NGOs, 25 food scholars, 15 civil servants in local, national and international institutions and 17 professionals in for-profit food entities. There are social entrepreneurs and food activists working or volunteering in social innovations geared towards improving the sustainability and fairness of food production and consumption, paid professionals and civil servants working in institutions that exert a leverage on the global governance of the food system (UN, EU, ministries, international and national NGOs), academics (senior and PhD students) focused on analyzing the nuances of the food system and innovative civic collective actions for food, either legally formed or self-regulated, that are building alternative niches to the dominant industrial food system regime. The activists are mostly senior professionals with more than 3 years of food-related experience (one fourth has actually an extensive experience on food issues). Country wise, there are respondents from 21 countries in all regions, U.S. (14), the U.K. (11) and Belgium (8) being the best represented and having only one respondent from Africa (Kenya) and Asia (Indonesia). In Tables S3-S5 of Supplementary Materials there are lists with the food actor's position, institution and country. Regarding food activism, most of them $(91.6 \%)$ are socially-/environmentally-conscientious eaters, either choosing often local and organic food or recycling and reducing waste (see Table S1 in Supplementary Material).

Within the self-described sectors of food activity, the not-for-profit sector prevails (see Table S1 in Supplementary Materials), with almost half of the respondents, the public sector represents one third and the for-profit sector the least represented (17.9\%). It is worth mentioning that this sample does not include people working for agri-food companies, either big transnational corporations or small-medium enterprises, which actually represents a limitation to interpret the results of this analysis. The different agri-food corporations and private initiatives contacted (nearly 70) did not reply to the questionnaire. This bias towards not-for-profit and public institutions (either state or civic) will be considered in the analysis. In that sense, due to the methodological bias, the global sample cannot pretend to depict the variety of food values and food policy beliefs that are present in the global landscape (as food valuations by important players in the industrial food system are almost absent), but to represent the dominant food policy beliefs in the two major types of alternatives to the dominant industrial food discourse: the reformers and the transformers. Likewise, the reforming stance cannot be split into two streams to fine-tune the analysis (i.e., neoliberal and gradual reformist), because the neoliberal stream would surely be under-represented. 


\section{Results}

The descriptive statistical results of the three agency variables (position in the transition landscape, political attitude and food valuation) plus the preferred food policy beliefs are presented in the Supplementary Materials to avoid the excessive length of the main text. In this section, only the correlation and regression analyses of the studied variables will be included.

\subsection{Correlation Analysis}

In order to understand the relationships between the three agency variables, univariate correlations were done between the variables at first level. The self-placement in the transition landscape (regime/niches) is not significantly correlated either to the political stance of the food-related activity or to the valuation of different food dimensions (cf. Table 1). The respondents working in the regime $(N=34)$ are equally likely to be gradual reformers $(N=12)$, counter-hegemonic transformers $(N=11)$ or alter-hegemonic transformers $(N=11)$. However, the respondents from the niches $(N=61)$ are three times more likely to be transformers $(N=48)$ than to be gradual reformers $(N=13)$ (cf Table S6a). Yet, this correlation is not significant at the 95\% level. Regarding the valuation of food, those working in the regime are more likely to be multi-dimensional $(N=20)$ than mono-dimensional $(N=14)$, a situation that is mirrored in the niches where multi-dimensionals $(N=39)$ almost double mono-dimensionals $(N=22)$. From the transitional perspective, the self-described position of any given food activist in the food system landscape cannot be significantly correlated with his/her political attitude vis à vis the existing (or desirable) food system nor with his/her valuation of different food dimensions.

Table 1. Correlations amongst the agency variables.

\begin{tabular}{lcccccc}
\hline & MO & MT & RE & NI & GR & TR \\
\hline Mono-dimensional cluster (MO) & 1 & & & & & \\
Multi-dimensional cluster (MT) & & 1 & & & & \\
Regime (RE) & 0.050 & -0.050 & 1 & & & \\
Niches (NI) & -0.050 & 0.050 & & 1 & & \\
Gradual Reformer (GR) & $0.272^{*}$ & $-0.272 *$ & 0.152 & -0.152 & 1 & \\
Transformer (TR) & $-0.272^{*}$ & $0.272 *$ & -0.152 & 0.152 & & 1 \\
\hline \multicolumn{7}{c}{ * Correlations significant at 95\% level. }
\end{tabular}

On the contrary, the valuation of food (economic vs. non-economic dimensions) is significantly correlated with the political stance vis à vis the food system (cf. Table 1). Those who consider themselves as gradual reformers $(N=25)$ are positively correlated with the mono-dimensional valuation of food $(N=15)$, whereas the transformers $(N=70)$ are significantly correlated with the multi-dimensional valuation of food $(N=49)$ (cf Table $S 6 b)$.

To fine tune this analysis, the initial agency variables where broken down into second level variables (cf. Table 2). In this view, the self-placement in the transition landscape shows significant and positive correlations with the political stance in two cases: the alter-hegemonic attitude is correlated with revolutionary niches and counter-hegemonic actions with small-niches. It is worth mentioning that those who describe their food-related activity as "a revolutionary niche" $(N=18)$ are more prone to "build a different food system" $(N=12)$ than to "struggle against the existing one" $(N=3)$. Conversely, those who "struggle against the system" in niches $(N=21)$ are more likely to consider themselves more humbly as "small niches" $(N=11)$ and not as "revolutionary" $(N=3)$ (cf. Table 3).

With regard to the food dimensions, those who value food as a strongly mono-dimensional good $(N=18)$ are significantly correlated with the political stance vis à vis the food system, positively in the case of being a gradual reformer $(N=10)$ and negatively in the case of counter-hegemonic transformers $(N=2)$ (cf Table S6b). Conversely, the multi-dimensional valuation of food $(N=59)$ is positively correlated with counter-hegemonic transformers $(N=25)$ and negatively with gradual reformers $(N=10)$. In this case, the alter-hegemonic political stance $(N=38)$ is not significantly correlated with 
any particular valuation of the food dimension. Those who seek to "build a different food system" can be Strongly Mono-Dimensional (SMD) $(N=6)$, Mildly Mono-Dimensional (MMD) $(N=8)$ or Multi-Dimensional (MTD) $(N=24)$. More specifically, the alter-hegemonic transformers working in revolutionary niches $(N=12)$ are split into mono-dimensional $(N=3)$ and multi-dimensional $(N=9)$. Finally, the intermediary group of those who value food as MMD $(N=18)$ is not significantly correlated with any political stance or placement in the transition landscape.

Table 2. Correlations amongst the split agency variables.

\begin{tabular}{|c|c|c|c|c|c|c|c|c|c|c|}
\hline & SMD & MMD & MTD & RE & SNI & ANI & RNI & GR & AHT & CHT \\
\hline Strongly Mono-Dimensional (SMD) & 1 & & & & & & & & & \\
\hline Mildly Mono-Dimensional (MMD) & & 1 & & & & & & & & \\
\hline Multi-Dimensional (MTD) & & & 1 & & & & & & & \\
\hline Regime (RE) & -0.024 & 0.087 & -0.050 & 1 & & & & & & \\
\hline Small Niche (SNI) & 0.001 & -0.128 & 0.102 & & 1 & & & & & \\
\hline Alternative Niche (ANI) & -0.010 & 0.116 & -0.085 & & & 1 & & & & \\
\hline Revolutionary Niche (RNI) & 0.040 & -0.096 & 0.045 & & & & 1 & & & \\
\hline Gradual Reformer (GR) & $0.321 *$ & 0.016 & $-0.272 *$ & 0.152 & -0.145 & 0.068 & -0.105 & 1 & & \\
\hline Alter-Hegemonic (AHT) & -0.065 & 0.043 & 0.017 & -0.116 & -0.072 & -0.040 & 0.263 * & & 1 & \\
\hline Counter-Hegemonic (CHT) & $-0.230 *$ & -0.060 & $0.235^{*}$ & -0.021 & $0.210 *$ & -0.021 & -0.174 & & & 1 \\
\hline
\end{tabular}

Table 3. Political stance and food valuation in niches $(\mathrm{N}=61)$.

\begin{tabular}{lcccc}
\hline & & & Mono-Dimensional $\mathbf{N = 2 2}$ & Multi-Dimensional $\mathbf{N}=\mathbf{3 9}$ \\
\hline $\begin{array}{l}\text { Self-placement in the } \\
\text { transition landscape }\end{array}$ & $\begin{array}{c}\text { Political stance vis à vis the } \\
\text { food system (self-placement) }\end{array}$ & $N$ & & \\
\hline Small-niche & Gradual reformer & 3 & 2 & 1 \\
$N=21$ & Counter-hegemonic & 11 & 2 & 9 \\
& Alter-hegemonic & 7 & 2 & 5 \\
\multirow{2}{*}{ Alternative } & Gradual reformers & 7 & 5 & 2 \\
$N=22$ & Counter-hegemonic & 7 & 5 & 2 \\
& Alter-hegemonic & 8 & 5 & 3 \\
\multirow{2}{*}{ Revolutionary } & Gradual reformer & 3 & 2 & 1 \\
$N=18$ & Counter-hegemonic & 3 & 1 & 2 \\
& Alter-hegemonic & 12 & 3 & 9 \\
\hline
\end{tabular}

\subsection{Regression Analysis}

Finally, a regression analysis was carried out (cf. Table 4) between the only agency variable (valuation of food) that is significantly correlated with political attitude, the preferred food policy beliefs that are significantly different and the other independent variables (country, age, gender, food-related experience, self-described sector of food activities and personal involvement in food activities). Additionally, two questions from the pairwise list were also included, as they proved to be relevant. Multiple regressions have been run by using different combinations of variables, and Table 4 presents the combinations that better represent the outcome variable. Although the regression does not explain causal relationships, the gradual reforming attitude is positively and strongly correlated with a strongly mono-dimensional valuation of food as a commodity and a middle age public sector employee that defends two dominant mantras so characteristic of the industrial agriculture paradigm, namely "the current food system is capable of producing sustainable food" and "food has to be beautiful and cheap", chiefly to facilitate food access (lowering the price) to urban consumers, disregarding rural producers. As those respondents are arguably concerned with the sustainability of the current food system, they work to improve the situation by supporting gradual reforms that merely adjust the system flaws and reverse the side-effects, since the system is capable of producing better food without the need of a drastic change. It is worth mentioning that members of this group are negatively correlated with "being part of a group to increase public awareness", which may suggest that they are not particularly active food activists. The list of respondents that fit with this group is presented in Supplementary Materials (cf Table S10). 
Table 4. Regression analysis with food valuation and other independent variables.

\begin{tabular}{|c|c|c|c|c|c|c|}
\hline $\begin{array}{l}\text { Dependent Variable: Political Stance } \\
\text { via à vis the Food System }\end{array}$ & & & & & & \\
\hline & \multicolumn{3}{|c|}{$\begin{array}{l}\text { Gradual Reformers } \\
N=25 \text { (against } 70 \text { ) }\end{array}$} & \multicolumn{3}{|l|}{$\begin{array}{l}\text { Counter-Hegemonic Transformers } \\
\qquad N=32 \text { (against 63) }\end{array}$} \\
\hline & & Signif & Coef. & & Signif. & Coef. \\
\hline \multicolumn{7}{|c|}{ Independent agency variables } \\
\hline $\begin{array}{l}\text { Valuation of food (confronting economic } \\
\text { and non-economic dimensions) }\end{array}$ & Strongly Mono-dimensional & $(+)^{* * *}$ & 1.8822 & Multi-dimensional & $(+)^{* *}$ & $0.810 \varsigma$ \\
\hline \multirow{2}{*}{ Food policy beliefs } & $\begin{array}{l}\text { Current food system capable of } \\
\text { producing sustainable food }\end{array}$ & $(+)^{* * *}$ & 1.5076 & $\begin{array}{l}\text { Living organisms (seeds or genes) shall not be patented } \\
\text { by individuals or corporations }\end{array}$ & $(+)^{* * *}$ & 1.4797 \\
\hline & Food has to be beautiful and cheap & $(+)^{* * *}$ & 1.2485 & $\begin{array}{l}\text { Freedom from hunger is a human right as important as } \\
\text { the right not to be tortured }\end{array}$ & $(+)^{* *}$ & 0.8400 \\
\hline \multicolumn{7}{|c|}{ Control variables } \\
\hline Country & Hunger stricken country & $(+)$ & 0.5344 & Hunger stricken country & $(+)^{* * *}$ & 1.4226 \\
\hline Age & Age between $31-50$ & $(+)^{* *}$ & 1.0998 & Age above 50 & $(-)$ & 0.3354 \\
\hline Gender & Male & $(+)$ & 0.5327 & Male & $(+)$ & 0.1632 \\
\hline Food related experience & Between 3-10 years of experience & $(-)^{* *}$ & 0.7608 & More than $10 \mathrm{y}$ & $(+)$ & 0.0171 \\
\hline Self-described sector of food activities & Public sector & $(+)^{* *}$ & 0.8536 & Self-regulated collective action Informal arrangement & $(+)^{* * *}$ & 1.1255 \\
\hline \multirow[t]{2}{*}{ Personal involvement in food activities } & $\begin{array}{l}\text { Being part of a group to increase } \\
\text { public awareness }\end{array}$ & $(-)^{* *}$ & 0.8363 & Sensitizing close relatives & $(+)$ & 0.3762 \\
\hline & $\begin{array}{l}\text { Probability }>F=0 \\
\text { Observations } N\end{array}$ & 007 & & $\begin{array}{l}\text { Probability }>F=0.0008 \\
\text { Observations } N=95\end{array}$ & & \\
\hline
\end{tabular}

Note: Maximum likelihood estimates of the probit models. Significance (Signif.) ${ }^{* * *}$ statistically significant at the $1 \%{ }^{* *}$ statistically significant at the $5 \%$ level. The numbers in the table are the coefficients (Coef.) of the regression equation. Note that the table shows associations, not necessarily causal relationships. 
On the other side, the counter-hegemonic transformative attitude is strongly correlated with the multi-dimensional valuation of food as a commons and a job in a self-regulated collective action with informal arrangements in a hunger-stricken country (i.e., civil society in the Global South). Two human-rights and commons-based policy beliefs are strongly preferred by this group, namely the opposition against patents on living organisms and the preference of freedom from hunger as a human right. In this regression, age, gender, food-related experience or personal involvement in food activities (either as self-producer, committed consumer or food activist) do not seem to have explanatory power to determine the political attitude vis à vis the existing food system and the valuation of food dimensions. The list of respondents that corresponds to this profile is presented in Supplementary Materials (cf Table S11).

\section{Discussion}

This research examines the links between the valuation of food, the transformative attitudes, the self-positioning in the transitional landscape and the preferred food policy beliefs of a community of practice formed by food-related professionals active in social networks. The estimated total size of this community is counted in millions, and therefore, the sample is far from being representative. Moreover, it is rather diverse, coming from 21 countries and more than 85 different institutions, although most of them are aware food consumers and two thirds committed food activists. Yet, this diversity may be considered a good representation of individuals working in the global food system, therefore sampling the values and shared beliefs on food found at landscape level. This research shall thus be seen as a first case-study with direct interviews on how people value food (either as a commons or a commodity) and how and if this valuation shapes food policy options and political attitudes.

The main weaknesses of the sample lays in the low representation of professionals working in the for-profit sector (only 17.9\%), whereas one third is working in the public sector (33.7\%), and almost half of the respondents are situated in the not-for profit third sector $(48.4 \%)$. That unequal distribution in the respondent's institution profit-orientation seems to be correlated to the lower figures of mono-dimensional respondents. However, this correlation has not been further explored in this paper.

\subsection{Great Diversity in the Regime and Niches Is Not Always Transformational}

Common sense states that people working in the regime would trend to maintain the status quo. Yet, contrary to expectations grounded on transition literature $[119,120]$, our research shows the respondents working in the regime (mostly in not-for profit institutions) can adopt diverse attitudes to change the food system (reformist, counter-hegemonic or alter-hegemonic), being none more likely than the others. Therefore, gradual reformers are not dominant in the regime. Besides, gradual reformers are equally split between the regime and niches. Finally, the valuation of food is not so evidently biased towards mono-dimensionality $(41.2 \%)$, with multi-dimensionality still prevailing $(58.8 \%)$. Therefore, the regime encompasses a great diversity of political attitudes and food valuations. Platitudes, generalities and stereotypes mask a more complex relationship between individual attitudes, institutional mandates and self-regarding.

On the other side, the niches are supposed to be loci of contestation [121], which is confirmed in this research as the respondents from the niches being three times more likely to be transformers than to be gradual reformers, as expected by the literature - however, the correlation is not significant, which may be due to the sample diversity, the low representation of the private sector, the low sample size or any other statistical artefacts. Yet, $21.3 \%$ of niche respondents only aim to reform the regime. The valuation of food as a multi-dimensional resource almost doubles the mono-dimensional valuation, although the figures are not statistically significant.

Working in regime institutions or so-called alternative niches is not significantly correlated with any specific political stance or food valuations. Not all confrontational or revolutionary food activists are working in the fringes, nor do all regime civil servants see food as a commodity and just want 
to maintain the status quo by promoting minimal reforms. It is important to notice that reformers and transformers can be found either in the dominant regime or in the innovative niches, as the self-perception of anyone's position in the food system transition and the political stance vis à vis the dominant narratives are personal attitudes and do not necessarily correspond to the institutional mandate or the real political decisions. Actually, the dominant regime accepts a certain amount of deviation from the hegemonic narrative and plurality of actions within the main transition pathway (i.e., organic niches, waste reduction), whereas the innovative niches (by default, aimed at changing or modifying the regime performance) present different degrees of confrontation with the regime, from gradual reforming to radical reversing, from working in fringes to embedding [16].

Within the same organization, multiple individual attitudes vis à vis the transition in the food system may be harbored. In that sense, transformative collective actions for food do not escape from having internal contradictions with regard to political attitudes [16], as we have seen in this study, with members of civic collective actions having a mono-dimensional view of food as a commodity (i.e., citizen initiative “Despertemos Guatemala" or Disco Soup Paris and Lille).

\subsection{Valuation of Food Is Correlated with Political Attitudes in Food Transitions}

However diverse the sample may be, the results respond to the first question of this research and show that the way each food professional values food, either as a commons or as a commodity, is significantly correlated with the political attitude adopted vis à vis the food system, regardless of the self-assigned position of the respondent's institution in the transition landscape. Those who consider themselves as gradual reformers, either working in the regime or in niches, are positively correlated with the mono-dimensional valuation of food, whereas the transformers, either alter or counter-hegemonic, are significantly correlated with the multi-dimensional valuation of food as a commons. Due to the sample size and statistical limitations, causal analysis cannot be inferred (the results cannot claim that those who see food as a mono-dimensional good adopt a reformist attitude in the food system, or vice versa), but the relationships are relevant. An important cautionary reminder: this relationship apply to members of not-for-profit institutions and public workers, and it cannot be extrapolated to private sector professionals. Further research is needed to further understand the private sector attitudes.

Deepening the analysis, those who value food as a strongly mono-dimensional good (the hardliners of food as a pure commodity) are positively correlated with gradual reformers and negatively with the counter-hegemonic transformers. Conversely, the defenders of a multiple-valuation of food as a commons are positively correlated with counter-hegemonic transformers and negatively with gradual reformers. It is worth mentioning that the alter-hegemonic transformers (those who seek to "build a different food system") are not significantly correlated with any particular valuation of the food dimension, nor any locus in the transition landscape, and yet, they often tend to consider themselves as working in "revolutionary niches". As expected, the intermediary and diverse group of those who value food as mildly mono-dimensional (that could also be interpreted as mildly-multidimensional) cannot be correlated to any political stance or placement in the transition landscape.

\subsection{Alter-and Counter-Hegemonic Attitudes Challenge the Regime Differently}

Although alter- and counter-hegemonic attitudes are both considered innovative and transformative, the way they challenge the system differs, and that may be partially explained by the different valuation of food they hold. Many alter-hegemonic professionals, whose attitude can be defined as alternative or interstitial, are aware of the major fault lines of the current system, but at the same time recognize the paramount difficulties to change the dominant regime, so they prefer to work through incremental erosion (i.e., Food Cardiff, Food Ethics Council), in fringes not fully explored by the regime (i.e., Commons Strategies Group, Australian Food Sovereignty Alliance), ignoring the state (i.e., Food Guerrilla, Commonsfest), locally (i.e., Group de Consum Ecologic I local del Terraprim) and doing things rather than protesting (i.e., Local Organic Food Co-ops Network). Generally speaking, 
they rather prefer building a different food system at the local level that satisfies their aspirational goals and the day-to-day access to healthy and fair food.

On the other side, the counter-hegemonic position seeks to uproot deep structures and build a new configuration based on different values. The position is thus quite political, denouncing flaws and inequalities and having a marked normative contestation [122]. The results confirm this definition since the normative (and different) valuation of food as a commons is positively and significantly correlated with this group and not with the alter-hegemonic one. Our results are also aligned with Johnston [114], who stated that reclaiming the commons characterized the counter-hegemonic potential of food-related activities. Actually, civic collective actions for food-food-related actions promoted by individual people, civic movements (legally formed or self-regulated) or formal non-governmental organizations that seek to produce, transform, distribute and consume food differently from the industrial food system-where citizens are devoting leisure time to food-related activities have been termed as counter-hegemonic [123], as they are innovative in their means, values, governance systems and institutional setup, develop alternative narratives to the dominant regime, and many of them seek to challenge, disrupt, modify or replace the regime practices, these days epitomized by the industrial food system. In our sample, the following respondents represent that group well: Souper Saturday, Incredible Edible Bratislava, Slow Food Youth Network, Confitures Re-belles, Re-bon Gleaning Network, Proyecto AliMente, Falling Fruit and Part-time Carnivore.

Plenty of scholars $[16,114,124]$ have pointed out that the alter-hegemonic attitude may not be transformative enough, since it does not question the structural principles of neoliberal markets. This constituency may inadvertently reinforce the "neoliberal narrative" through: (a) their discursive emphasis on personal responsibility, voluntary action, competition and efficiency [125]; (b) de-politicizing food politics and placing the transformative agency on the shoulders of conscientious consumers, innovative entrepreneurs and well-intended volunteers [126]; (c) emphasizing entrepreneurial solutions and local market linkages, thus obscuring the importance of state duties and citizen entitlements [127]; and (d) having a local focus rather than a national one [128], thus contributing to the process of devolution often associated with neoliberalism [129]. By de-politicizing food politics, these initiatives conform with the discourse that re-labels citizens with a right to food guaranteed by the State into consumers with food choices and responsibilities. There are 14 respondents that consider themselves alter-hegemonic and yet do align with the neoliberal narrative of food as a commodity (see Table S5 in Supplementary Materials). Among those, one can find social entrepreneurs, ministerial officers, European university researchers, international NGOs and members of food councils.

\subsection{Combining Agency with Food Policy Beliefs}

Regarding the second question (policy beliefs associated with valuations of food), the analysis shows that only two policy beliefs out of $12(16.6 \%)$ are significantly different between the strongly mono-dimensionals (SMD) and the multi-dimensionals (MTD), but both fit with the "a priori" expected pattern. Although food policy belief preference is rather dispersed, logically mirroring the sample diversity, some significant patterns have been identified that link the mono-dimensional cluster with the non-preference of certain food policy beliefs that clearly challenge the dominant narrative of the neoliberal industrial food system, such as "banning financial speculation of food products" [130], "prohibiting patents on living organisms" [131] or "establishing Universal Food Programmes to guarantee food to those who cannot afford it" [132] (see Tables S8 and S9 in Supplementary Materials).

In all of the relative preferences and in half the absolute ones, the mildly-mono-dimensionals (MMD) score between the SMD and the MTD except in one very striking policy belief, the consideration that "Food and nutrition security is a global public good", where SMD preferences are similar to MTD ones (around 72\%) and much higher than MMD preferences. This policy belief emerges as the most preferred by the most contrasting groups. It is rather awkward to see the commodity hardliners defend that food policy belief. Usually, the only food-related elements that were accepted by the neoliberal mainstream as global public goods were those that facilitate free trade and transboundary 
competition [133] (p. 43), such as binding WTO agreements, mechanisms to guarantee stability in food markets [134] and strategic food grain reserves [135]. Global public goods are goods that are governed in a common manner as they are beneficial for every human being [95]. Although providing an explanation is beyond the scope of this paper, one suggestive justification may lay in the world "global" that firstly deviates from the idea of food as a public good at the local or national level, positioning the debate to international fora where binding obligations become often diluted; and secondly, it conveys a moral meaning where many people can find a common ground ("food is important for individuals and societies"; "food is a special resource"), but by being global, it does not threaten the institutional set up of the current national food systems. It is perceived as desirable and harmless and, at the same time, being a beautiful aspirational sentence that fits well with a socially-desirable response with no practical implications (at least not in the respondent's view).

\section{Conclusions}

The dominant narrative in the industrial food system justifies food to be produced at the lowest cost and to be sold where the utilities are the highest, disregarding social and environmental consequences. Since this system is in crisis, perhaps time has come to think outside the permitted ideas and value food as a commons to be governed for everybody's interest. Once the way we see food is modified, policies, legal frameworks, incentives and governance arrangements will also change.

This paper explains the normative consideration of food as a multi-dimensional commons, with six economic and non-economic dimensions that are equally relevant to human beings. Due to that relevance, food cannot be solely left to money-mediated profit-seeking rules for production, allocation and access. This consideration is a political social construct, and we have explored how relevant it may be to sustain transformative alternatives of transition.

It is worth mentioning that this social construct is at odds with the most prominent alternative discourses that are confronting the hegemonic productivist narrative. After an exhaustive scrutiny (see Vivero-Pol for a systematic review of scholarly literature [136]), only a few authors that consider food as a commons have been found $[137,138]$. Citizens and consumers accept as "normal" the social construct privileged by the elites that justifies the commodification of food, and thus, the manufacturing of consent emerges from a bottom-up normalization [14,139].

This research has found that the socially-constructed view of "food as a commodity" is associated with the reformist attitude, no matter where the person positions himself/herself (regime or niches). Conversely, "food as a commons" is a belief associated with the counter-hegemonic transformative attitude. Exceptions can be found in each group, and yet, the correlations are strongly significant and commonsensical.

The results contribute to agency-sensitive analysis in food transitions by validating the hypothesis that the way food professionals value food is related to the political attitude with regard to the existing food system and its transition trajectories, although no causality can be inferred by this sample. In other words the normative consideration of food shapes the priorities for action (political attitude) and, to a certain extent, specific food policies we support/accept (preferred policy beliefs). Since beliefs and values drive transition pathways, the consideration of food as a commons will certainly open up new policy options and regenerative claims in the future.

Moreover, the hegemonic consideration of food as a commodity is challenged from within and outside. Multiples loci of resistance with counter-hegemonic attitudes are challenging the hegemonic paradigm. These diverse people in rather diverse institutions have a set of shared food policy beliefs and a convergent regard of food as a commons. If power is exercise in multiple locations with paradigms normalizations, counter-hegemonic resistance defending food as a commons requires multiple projects to de-normalize the assumed paradigm associated with the hegemonic industrial food system.

The multiple valuation of food as a commons may enrich the diversity of transformative alternatives (food justice, food sovereignty, de-growth, commons, epistemologies from the South, 
transition towns, veganism, right to food, food security, nutrition transition), including those more transformative or more reformist. The commodification of food will consist of a long-term incremental process to dismantle the absolute reliance on market logic [114], a process that is led by transnational food movements in the international arena [140], but that needs to be complemented and re-enforced by local food movements working in customary and contemporary alter- and counter-hegemonic niches in order to build a "globalization from below" [141]. Eat locally, but re-claim globally.

Supplementary Materials: The following are available online at www.mdpi.com/2071-1050/9/3/442/s1, Table S1: Simple and composite variables, Table S2: Composite variable to analyse mono- and multi-dimensionality of food valuation, Table S3: Gradual Reformers $(N=25)$, Table S4: Counter-hegemonic Transformers $(N=32)$, Table S5: Alter-hegemonic Transformers $(N=38)$, Table S6: Features of individual agency in food system transitions, Table S7: Several examples of counter-intuitive agency in food system transition, Table S8: Preferred Food Policy Beliefs and political stance clusters, Table S9: Preferred Food Policy Beliefs and valuation of food dimensions, Table S10: Gradual Reformers + Strongly Mono-dimensional $(N=10)$, Table S11: Counter-hegemonic Transformers + multi-dimensional $(N=20)$.

Acknowledgments: The author gratefully acknowledges co-funding from the Belgian Science Policy Office, under the project Food4Sustainability (BRAIN-be contract BR/121/A5) and the European Commission, under the PF7-projects BIOMOT (Grant Agreement 282625, www.biomotivation.eu) and GENCOMMONS (ERC Grant Agreement 284). The open-access publication was funded through an EU OpenAire Fp-7 postgrant (https: //postgrantoapilot.openaire.eu). Content-wise, the author thanks the relevant suggestions and the reviewing work done by the reviewers and the editor, especially the indications to shorten and re-arrange the text.

Conflicts of Interest: The author declares no conflict of interest.

\section{Abbreviations}

The following abbreviations are used in this text:

$\begin{array}{ll}\text { BIOMOT } & \begin{array}{l}\text { Motivational strength of ecosystem services and alternative ways to express the value } \\ \text { of biodiversity }\end{array} \\ \text { BRAIN-be } & \text { Belgian Research Action through Interdisciplinary Networks } \\ \text { EU } & \text { European Union } \\ \text { FAO } & \text { Food and Agriculture Organisation of United Nations } \\ \text { GENCOMMONS } & \begin{array}{l}\text { Institutionalizing global genetic-resource commons. Global Strategies for accessing and } \\ \text { using essential public knowledge assets in the life sciences }\end{array} \\ \text { GMO } & \text { Genetically-Modified Organisms } \\ \text { MMD } & \text { Mildly Mono-Dimensional } \\ \text { MTD } & \text { Multi-Dimensional } \\ \text { MLP } & \text { Multi-Level Perspective on sustainable transitions theory } \\ \text { NGO } & \text { Non-Governmental Organization } \\ \text { OECD } & \text { Organisation of Economic Cooperation and Development } \\ \text { SDR } & \text { Socially-Desirable Responses } \\ \text { SMD } & \text { Strongly Mono-Dimensional } \\ \text { U.K. } & \text { United Kingdom } \\ \text { UN } & \text { United Nations } \\ \text { U.S. } & \text { United States of America } \\ \text { WTO } & \text { World Trade Organisation }\end{array}$

\section{References}

1. Francis, P. Laudato si. Praise Be to You-On Care for Our Common Home. Encyclical, 24 May 2015. Available online: http://w2.vatican.va/content/dam/francesco/pdf/encyclicals/documents/papa-rancesco_ 20150524_enciclica-laudato-si_en.pdf (accessed on 15 March 2017).

2. La Via Campesina (LVC). Agroecology as a Way of Life. First Assembly of the Alliance for Food Sovereignty of Latin America and the Caribbean. 2013. Available online: https://viacampesina.org/en/index.php/mainissues-mainmenu-27/sustainable-peasants-agriculture-mainmenu-42/1480-agroecology-as-a-way-of-life (accessed on 15 March 2017).

3. McMichael, P. Historicizing food sovereignty. J. Peasant Stud. 2014, 41, 933-957. [CrossRef] 
4. McColl, K. Can we feed the world? Interview with Olivier de Schutter. Br. Med. J. 2008, 336, $1336-1338$. [CrossRef] [PubMed]

5. Agyeman, J.; McEntee, J. Moving the field of food justice forward through the lens of urban political ecology. Geogr. Compass 2014, 8, 211-220. [CrossRef]

6. Edenhofer, O.; Flachsland, C. Laudato si'. Die Sorge um Die Globalen Gemeinschaftsgüter. Stimmen der Zeit 2015, 9, 579-591. Available online: https://www.thinkingfaith.org/articles/laudato-si\%E2\%80\%99-concernour-global-commons (accessed on 15 March 2017).

7. Locke, J. Two Treatises of Government; Essay 2, Chapter V; Laslett, P., Ed.; Cambridge Texts in the History of Political Thought; Cambridge University Press: Cambridge, UK, 1988.

8. Millstone, E.; Lang, T. The Penguin Atlas of Food; Penguin Books: New York, NY, USA, 2003.

9. De Schutter, O. The Transformative Potential of the Right to Food. Report of the Special Rapporteur on the Right to Food to the UN Human Rights Council. A/HRC/25/57. 2014. Available online: http://www. srfood.org/images/stories/pdf/officialreports/20140310_finalreport_en.pdf (accessed on 15 March 2017).

10. Rosin, C.; Stock, P.; Campbell, H. Introduction: Shocking the global food system. In Food Systems Failure: The Global Food Crisis and the Future of Agriculture; Rosin, C., Stock, P., Campbell, H., Eds.; Earthscan: London, UK, 2012; pp. 1-14.

11. Lang, T. Crisis? What crisis? The normality of the current food crisis. J. Agrar. Chang. 2010, 10, 87-97. [CrossRef]

12. Sage, C. The transition movement and food sovereignty: From local resilience to global engagement in food system transformation. J. Consum. Cult. 2014, 14, 254-275. [CrossRef]

13. Russi, L.; Ferrando, T. 'Capitalism A Nuh' Wi Frien'. The Formatting of Farming into an Asset, from Financial Speculation to International Aid. Catal. Soc. Justice Forum 2015, 6, 7. Available online: http: / / trace.tennessee.edu/catalyst/vol6/iss1/7 (accessed on 15 March 2017).

14. Gramsci, A. Selections from the Prison Notebooks of Antonio Gramsci; International Publishers: New York, NY, USA, 1971.

15. Holt-Giménez, E.; Shattuck, A. Food crises, food regimes and food movements: Rumblings of reform or tides of transformation? J. Peasant Stud. 2011, 38, 109-144. [CrossRef] [PubMed]

16. McClintock, N. Radical, reformist, and garden-variety neoliberal: Coming to terms with urban agriculture's contradictions. Local Environ. 2014, 19, 147-171. [CrossRef]

17. Williams, R. Marxism and Literature; Oxford University Press: Oxford, UK, 1977.

18. Wright, E.O. Compass Points. Towards a Socialist Alternative. New Left Rev. 2006, 41, 93-124.

19. Steffen, W.; Richardson, K.; Rockström, J.; Cornell, S.E.; Fetzer, I.; Bennett, E.M.; Biggs, R.; Carpenter, S.R.; de Vries, W.; de Wit, C.A.; et al. Planetary Boundaries: Guiding human development on a changing planet. Science 2015, 347. [CrossRef] [PubMed]

20. Lewis, S.L.; Maslin, M.A. Defining the Anthropocene. Nature 2015, 519, 171-180. [CrossRef] [PubMed]

21. Moore, J.W. Capitalism in the Web of Life: Ecology and the Accumulation of Capital; Verso Books: London, UK, 2015.

22. Tilman, D.; Fargione, J.; Wolff, B.; D'Antonio, C.; Dobson, A.; Howarth, R.; Schindler, D.; Schlesinger, W.H.; Simberloff, D.; Swackhamer, D. Forecasting Agriculturally Driven Global Environmental Change. Science 2001, 292, 281-284. [CrossRef] [PubMed]

23. Clapp, J. Food; Polity Press: Cambridge, UK, 2012.

24. Carolan, M. Reclaiming Food Security; Earthscan-Routledge: New York, NY, USA, 2013.

25. International Food Policy Research Institute. Global Nutrition Report 2016: From Promise to Impact: Ending Malnutrition by 2030, IFPRI: Washington, DC, USA, 2016.

26. Global Alliance for Improved Nutrition. Access to Nutrition Index. Global Index 2013. Global Alliance for Improved Nutrition, 2013. Available online: http://s3.amazonaws.com/ATN/atni_global_index_2013.pdf (accessed on 15 March 2017).

27. Food and Agriculture Organization of United Nations (FAO); The International Fund for Agricultural Development (IFAD); World Food Programme (WFP). The state of food insecurity in the world. In Meeting the 2015 International Hunger Targets: Taking Stock of Uneven Progress; FAO: Rome, Italy, 2015.

28. United Nations Conference on Trade and Development (UNCTAD). Wake up before It Is Too Late, Make Agriculture Truly Sustainable Now for Food Security in a Changing Climate; Trade and Environment Report 2013; UNCTAD: Geneva, Switzerland, 2013; pp. 19-21. 
29. Ng, M.; Fleming, T.; Robinson, M.; Thomson, B.; Graetz, N.; Margono, C.; Mullany, E.C.; Biryukov, S.; Abbafati, C.; Abera, S.F.; et al. Global, regional, and national prevalence of overweight and obesity in children and adults during 1980-2013: A systematic analysis for the Global Burden of Disease Study 2013. Lancet 2014, 384, 766-781. [CrossRef]

30. Black, R.E.; Victora, C.G.; Walker, S.P.; Bhutta, Z.A.; Christian, P.; de Onis, M.; Ezzati, M.; Grantham-McGregor, S.; Katz, J.; Martorell, R.; et al. Maternal and child undernutrition and overweight in low-income and middle-income countries. Lancet 2013, 382, 427-451. [CrossRef]

31. Cassidy, E.S.; PWest, C.; Gerber, J.S.; Foley, J.A. Redefining agricultural yields: From tonnes to people nourished per hectare. Environ. Res. Lett. 2013, 8, 034015. [CrossRef]

32. Gustavsson, J.; Cederberg, C.; Sonesson, U.; van Otterdijk, R.; Meybeck, A. Global Food Losses and Food Waste. Extent, Causes and Prevention; FAO: Rome, Italy, 2011; Available online: http:/ /www.fao.org/docrep/014/ mb060e/mb060e.pdf (accessed on 15 March 2017).

33. De Marsily, G. An overview of the world's water resources problems in 2050. Ecohydrol. Hydrobiol. 2007, 7, 147-155. [CrossRef]

34. Sablani, S.S.; Opara, L.U.; Al-Balushi, K. Influence of bruising and storage temperature on vitamin C content of tomato fruit. J. Food Agric. Environ. 2006, 4, 54-56.

35. Foresight. The Future of Food and Farming: Challenges and Choices for Global Sustainability; Final Project Report; The Government Office for Science: London, UK, 2011.

36. United Nations. The Future We Want. Outcome Document Adopted at the Rio+20 Conference. A/Res. 66/288. 2012. Available online: http://www.un.org/ga/search/view_doc.asp?symbol=A/RES/66/288\& Lang=E (accessed on 15 March 2017).

37. Food and Agriculture Organization of United Nations (FAO). The State of Food and Agriculture 2015. Social Protection and Agriculture: Breaking the Cycle of Rural Poverty; FAO: Rome, Italy, 2015.

38. Harvey, D. A Brief History of Neoliberalism; Oxford University Press: New York, NY, USA, 2005.

39. Polanyi, K. The Great Transformation: The Political and Economic Origins of Our Time; Farrar \& Rinehart Reprinted in 2001; Beacon Press: Boston, MA, USA, 1944.

40. Aistara, G.A. Seeds of Kin, Kin of Seeds: The Commodification of Organic Seeds and Social Relations in Costa Rica and Latvia. Ethnography 2011, 12, 490-517. [CrossRef]

41. Finger, M.; Allouche, J. Water Privatisation: Trans-National Corporations and the Re-Regulation of the Water Industry; Spoon Press: London, UK, 2002.

42. Borras, S.M.; Franco, J.C. Global land grabbing and trajectories of agrarian change: A preliminary analysis. J. Agrar. Chang. 2012, 12, 34-59. [CrossRef]

43. Lang, T.; Heasman, M. Food Wars: The Global Battle for Mouths, Minds and Markets, 2nd ed.; Earthscan from Routledge: London, UK, 2015.

44. Castree, N. Commodifying What Nature? Prog. Hum. Geogr. 2003, 27, 273-297. [CrossRef]

45. Clapp, J.; Fuchs, D. (Eds.) Corporate Power in Global Agrifood Governance; MIT Press: Cambridge, MA, USA, 2009.

46. Rocha, C. Food Insecurity as Market Failure: A Contribution from Economics. J. Hunger Environ. Nutr. 2007, 1, 5-22. [CrossRef]

47. D'Odorico, P.; Carr, J.A.; Laio, F.; Ridolfi, L.; Vandoni, S. Feeding humanity through global food trade. Earths Future 2014, 2, 458-469. [CrossRef]

48. Moore, J.W. Cheap Food \& Bad Money: Food, Frontiers, and Financialization in the Rise and Demise of Neoliberalism. Review 2010, 33, 225-261.

49. Drewnowski, A.; Darmon, N. The economics of obesity: Dietary energy density and energy cost. Am. J. Clin. Nutr. 2005, 82, 265-273.

50. O'Kane, G. What is the real cost of our food? Implications for the environment, society and public health nutrition. Public Health Nutr. 2012, 15, 268. [CrossRef] [PubMed]

51. Timmer, P.; Falcon, W.P.; Pearson, S.R. Food Policy Analysis; Johns Hopkins University Press: Washington, DC, USA, 1983.

52. McMichael, P. A food regime genealogy. J. Peasant Stud. 2009, 36, 139-169. [CrossRef]

53. Araghi, F. Food regimes and the production of value: Some methodological issues. J. Peasant Stud. 2003, 30, 41-70. [CrossRef] 
54. Beck, D.; Ivanovic, M.; Noll, S.; Werkheiser, I. The ethics of consuming: Community, agency, and participation in global food systems. In The Ethics Consumption: The Citizen, the Market and the Law; Röcklinsberg, H., Sandin, P., Eds.; Wageningen Academic Publishers: Wageningen, The Netherlands, 2013; pp. 437-447.

55. Magdoff, F.; Tokar, B. (Eds.) Agriculture and Food in Crisis. Conflict, Resistance, and Renewal; Monthly Review Press: New York, NY, USA, 2010.

56. Zerbe, N. Setting the global dinner table. Exploring the limits of the marketization of food security. In The Global Food Crisis. Governance Challenges and Opportunities; Clapp, J., Cohen, M.J., Eds.; The Centre for International Governance Innovation \& Wilfrid Laurier University Press: Waterloo, ON, Canada, 2009; pp. 161-175.

57. Sandel, M.J. What Isn't for Sale? In The Atlantic; 2012. Available online: http://www.theatlantic.com/ magazine/archive/2012/04/what-isnt-for-sale/308902/ (accessed on 25 February 2015).

58. Geels, F.W.; Schot, J. Typology of sociotechnical transition pathways. Res. Policy 2007, 36, 399-417. [CrossRef]

59. Geels, F.W. The multi-level perspective on sustainability transitions: Responses to seven criticisms. Environ. Innov. Soc. Trans. 2011, 1, 24-40. [CrossRef]

60. Elzen, B.; Geels, F.W.; Green, K. (Eds.) System Innovation and the Transition to Sustainability: Theory, Evidence and Policy; Edward Elgar: Cheltenham, UK, 2004; pp. 19-47.

61. Kemp, R.; Schot, J.; Hoogma, R. Regime shifts to sustainability through processes of niche formation: The approach of strategic niche management. Technol. Anal. Strateg. Manag. 1998, 10, 175-196. [CrossRef]

62. Sen, A.K. Well-Being, Agency and Freedom: The Dewey Lectures 1984. J. Philos. 1985, 82, 169-221. [CrossRef]

63. Alkire, S. Concepts and measures of agency. In Arguments for a Better World: Essays in Honor of Amartya Sen. Volume I: Ethics, Welfare, and Measurement; Basu, K., Kanbur, R., Eds.; Oxford University Press: Oxford, UK, 2008.

64. Narayan, D.; Petesch, P. Agency, Opportunity Structure, and Poverty Escapes. In Moving Out of Poverty. Cross-Disciplinary Perspectives on Mobility; Narayan, D., Petesch, P., Eds.; Palgrave Macmillan and the World Bank: Washington, DC, USA, 2007; Volume 1, pp. 1-44.

65. Kashima, Y.; Peters, K.; Whelan, J. Culture, Narrative, and Human Agency. In Handbook of Motivation and Cognition across Cultures; Sorrentino, R., Yamaguchi, S., Eds.; Academic Press: New York, NY, USA, 2008; pp. 393-421.

66. Smith, A.; Stirling, A.; Berkhout, F. The governance of sustainable socio-technical transitions. Res. Policy 2005, 34, 1491-1510. [CrossRef]

67. Meadowcroft, J. What about the politics? Sustainable development, transition management, and long term energy transitions. Policy Sci. 2009, 42, 323-340. [CrossRef]

68. Scrase, I.; Smith, A. The (non-) politics of managing low carbon socio-technical transitions. Environ. Politics 2009, 18, 707-726. [CrossRef]

69. Farla, J.C.M.; Markard, J.; Raven, R.; Coenen, L. Sustainability transitions in the making: A closer look at actors, strategies and resources. Technol. Forecast. Soc. Chang. 2012, 79, 991-998. [CrossRef]

70. Ingram, J. Framing niche-regime linkage as adaptation: An analysis of learning and innovation networks for sustainable agriculture across Europe. J. Rural Stud. 2015, 40, 59-75. [CrossRef]

71. Hinrichs, C.C. Transitions to sustainability: A change in thinking about food systems change? Agric. Hum. Values 2014, 31, 143-155. [CrossRef]

72. Vanloqueren, G.; Baret, P.V. How agricultural research systems shape a technological regime that develops genetic engineering but locks out agroecological innovations. Res. Policy 2009, 38, 971-983. [CrossRef]

73. Darnhofer, I. Socio-technical transitions in farming: Key concepts. In Transition Pathways towards Sustainability in European Agriculture. Case Studies from Europe; Sutherland, L.A., Darnhofer, I., Wilson, G.A., Zagata, L., Eds.; CAB International: Wallingford, UK, 2015; pp. 17-32.

74. Ellul, J. The Technological Bluff; Wm. B. Eerdmans Publishing Co.: Grand Rapids, MN, USA, 1990.

75. Malthus, T. An Essay on the Principle of Population: Or a View of Its Past and Present Effects on Human Happiness; with an Inquiry into our Prospects Respecting the Future Removal or Mitigation of the Evils Which It Occasions; Reeves and Turner: London, UK, 1798. (Published in 1872).

76. Grodzins-Gold, A. Food values beyond nutrition. In The Oxford Handbook of Food, Politics, and Society; Herring, R., Ed.; Oxford University Press: Oxford, UK, 2015; pp. 545-561.

77. Sumner, J. Serving Social Justice: The Role of the Commons in Sustainable Food Systems. Stud. Soc. Justice 2011, 5, 63-75. 
78. McMichael, P. The power of food. Agric. Hum. Values 2000, 17, 21-33. [CrossRef]

79. Vivero-Pol, J.L. What If Food Is Considered a Common Good? The Essential Narrative for the Food and Nutrition Transition; SCN News 40:85-89; UN Standing Committee on Nutrition: Geneve, Switzerland, 2014; Available online: https:/ / www.unscn.org/en/topics/sustainable-food-systems?idnews=1310 (accessed on 15 March 2017).

80. Vivero-Pol, J.L. Food is a public good. [The Food System]. World Nutr. 2015, 6, 306-309.

81. Maslow, A. A theory of human motivation. Psychol. Rev. 1943, 50, 370-396. [CrossRef]

82. Sen, A.K. Development as Freedom; Oxford University Press: Oxford, UK, 1999.

83. O'Neill, J. The overshadowing of needs. In Sustainable development: Capabilities, Needs and Well-Being; Studies in Ecological Economics; Rauschmayer, F., Omann, I., et Frühmann, J., Eds.; Routledge: London, UK, 2011; pp. 25-42.

84. Wiggins, D. Needs, Values, Truth: Essays in the Philosophy of Value; Oxford University Press: Oxford, UK, 1998.

85. Rawls, J. A Theory of Justice; Belknap Press: Cambridge, MA, USA, 1971.

86. Polanyi, K. The Livelihood of Man; H.W. Pearson: New York, NY, USA, 1977.

87. Holt-Giménez, E.; Shattuck, A.; Altieri, M.; Herren, H.; Gliessman, S. We Already Grow Enough Food for 10 Billion People... and Still Can't End Hunger. J. Sustain. Agric. 2012, 36, 595-598. [CrossRef]

88. De Schutter, O.; Pistor, K. Introduction: Toward voice and reflexivity. In Governing Access to Essential Resources; Pistor, K., De Schutter, O., Eds.; Columbia University Press: New York, NY, USA, 2015; pp. 3-45.

89. Max-Neef, M. Development and human needs. In Real-Life Economics-Understanding Wealth Creation; Ekins, P., Max-Neef, M., Eds.; Routledge: London, UK, 1992; pp. 197-213.

90. Stavenhagen, R. Needs, Rights and Social Development. Overarching Concerns Programme Paper Number 3; UNRISD: Geneva, Switzerland, 2003; Available online: http://www.unrisd.org/80256B3C005BCCF9/ search/504B939890CF44D1C1256D72004D184E?OpenDocument\&language=es (accessed on 15 March 2017).

91. United Nations. Universal Declaration of Human Rights. General Assembly Resolution 217 A (III). UN Doc. A/810, at 71 (1948). Available online: http://www.un-documents.net/a3r217a.htm (accessed on 15 March 2017).

92. United Nations. International Covenant on Economic, Social and Cultural Rights, Adopted on 16 December 1966, General Assembly Resolution 2200(XXII), UN. GAOR, 21st sess., Supp. No. 16, U.S. Doc. A/6316 (1966), 993 UNTS 3. Available online: https:/ / treaties.un.org/Pages/ViewDetails.aspx?src=IND\&mtdsg no=IV-3\&chapter=4\&clang=_en (accessed on 15 March 2017).

93. Clapham, A. Human Rights. A Very Short Introduction; Oxford University Press: Oxford, UK, 2007.

94. Samuelson, P.A. The pure theory of public expenditure. Rev. Econ. Stat. 1954, 36, 387-389. [CrossRef]

95. Kaul, I.; Mendoza, R.U. Advancing the concept of public goods. In Providing Global Public Goods: Managing Globalization; Kaul, I., Conceição, P., le Goulven, K., Mendoza, R.U., Eds.; Oxford University Press: Oxford, UK, 2003.

96. Montanori, M. Food Is Culture. Arts and Traditions on the Table; Columbia University Press: New York, NY, USA, 2006.

97. Rozin, P.; Remick, A.K.; Fischler, C. Broad Themes of Difference between French and Americans in Attitudes to Food and Other Life Domains: Personal versus Communal Values, Quantity versus Quality, and Comforts versus Joys. Front. Psychol. 2011, 2, 177. [CrossRef] [PubMed]

98. Fischler, C. Food, self and identity. Soc. Sci. Inf. 1988, 27, 275-292. [CrossRef]

99. Fraser, E.D.G.; Rimas, A. Empires of Food: Feast, Famine, and the Rise and Fall of Civilizations; Free Press: Toronto, ON, Canada, 2010.

100. Sobal, J.; Nelson, M.K. Commensal eating patterns: A community study. Appetite 2003, 41, $181-190$. [CrossRef]

101. The Economics of Ecosystems and Biodiversity (TEEB). The Economics of Ecosystems and Biodiversity for Agriculture \& Food: An Interim Report; United Nations Environment Programme: Geneva, Switzerland, 2015. Available online: http://img.teebweb.org/wp-content/uploads/2015/12/TEEBAgFood_Interim_Report_ 2015_web.pdf (accessed on 15 March 2017).

102. Schulp, C.J.E.; Thuiller, W.; Verburg, P.H. Wild food in Europe: A synthesis of knowledge and data of terrestrial wild food as an ecosystem service. Ecol. Econ. 2014, 105, 292-305. [CrossRef]

103. Christy, F.T.; Scott, A. The Common Wealth in Ocean Fisheries; Some Problems of Growth and Economic Allocation; Johns Hopkins Press: Baltimore, MD, USA, 1965. 
104. Bene, C.; Phillips, M.; Allison, E.H. The forgotten service: Food as an ecosystem service from estuarine and coastal zones. In Treatise on Estuarine and Coastal Science; Academic Press: Waltham, MA, USA, 2011; Volume 12, pp. 147-180.

105. Renger, J.M. Institutional, Communal, and Individual Ownership or Possession of Arable Land in Ancient Mesopotamia from the End of the Fourth to the End of the First Millennium B.C. Chicago-Kent Law Rev. 1995, 71, 11. Available online: http://scholarship.kentlaw.iit.edu/cklawreview/vol71/iss1/11 (accessed on 15 March 2017).

106. Linebaugh, P. The Magna Carta Manifesto. Liberties and Commons for All; University of California Press: Oakland, CA, USA, 2008.

107. Hardin, G. Living on a lifeboat. Bioscience 1974, 24, 561-568. [CrossRef] [PubMed]

108. Schlager, E.; Ostrom, E. Property-Rights Regimes and Natural Resources: A Conceptual Analysis. Land Econ. 1992, 68, 249-262. [CrossRef]

109. Wuyts, M. Deprivation and Public Need. In Development Policy and Public Action; Wuyts, M.E., Mackintosh, M., Hewitt, T., Eds.; Oxford University Press/Open University: Oxford, UK, 1992.

110. Capra, F.; Mattei, U. The Ecology of Law: Toward a Legal System in Tune with Nature and Community; Berrett-Koehler Publishers: San Francisco, CA, USA, 2015.

111. Lozano-Cabedo, C.; Gomez-Benito, C. A theoretical model of Food citizenship for the analysis of social praxis. J. Agric. Environ. Ethics 2016, 29, 1-22. [CrossRef]

112. Lang, T. Towards a food democracy. In Consuming Passions: Food in the Age of Anxiety; Griffiths, S., Wallace, J., Eds.; Manchester University Press: Manchester, UK, 2003; pp. 13-24.

113. Welsha, J.; MacRaeb, R. Food Citizenship and Community Food Security: Lessons from Toronto, Canada. Can. J. Dev. Stud. 1998, 19, 237-255. [CrossRef]

114. Johnston, J. Counterhegemony or Bourgeois Piggery? Food Politics and the Case of FoodShare. In The Fight over Food: Producers, Consumers, and Activists Challenge the Global Food System; Wright, W., Middendorf, G., Eds.; Pennsylvania State University: University Park, PA, USA, 2008; pp. 93-120.

115. Vivero-Pol, J.L. The food commons transition: Collective actions for food and nutrition security. In Autonomism and Perspectives on Commoning; Ruivenkamp, G., Hilton, A., Eds.; Zed Books: New York, NY, USA, 2017; pp. 185-221, unpublished.

116. Lave, J.; Wenger, E. Situated Learning: Legitimate Peripheral Participation; Cambridge University Press: Cambridge, UK, 1991.

117. Dubé, L.; Bourhis, A.; Jacob, R. The impact of structuring characteristics on the launching of virtual communities of practice. J. Org. Chang. Manag. 2005, 18, 145-166. [CrossRef]

118. Counihan, C.; Siniscalchi, V. (Eds.) Food Activism. Agency, Democracy and Economy; Bloomsbury Publishing: London, UK, 2013.

119. Geels, F.W. Technological transitions as revolutionary reconfiguration process: A multi-level perspective and a case study. Res. Policy 2002, 31, 1257-1274. [CrossRef]

120. Lawhon, M.; Murphy, J.T. Socio-technical regimes and sustainability transitions. Insights from political ecology. Prog. Hum. Geogr. 2012, 36, 354-378. [CrossRef]

121. Roep, D.; Wiskerke, J.S.C. Reflecting on novelty production and niche management in agriculture. In Seeds of Transition: Essays on Novelty Production, Niches and Regimes in Agriculture; Wiskerke, J.S.C., van der Ploeg, J.D., Eds.; Royal Van Gorcum: Assen, The Netherlands, 2004; pp. 341-356.

122. Elzen, B.; Geels, F.W.; Leeuwis, C.; van Mierlo, B. Normative contestation in transitions "in the making". Res. Policy 2011, 40, 263-275. [CrossRef]

123. Ravenscroft, N.; Moore, N.; Welch, E.; Hanney, R. Beyond agriculture: The counter-hegemony of community farming. Agric. Hum. Values 2013, 30, 629-639. [CrossRef]

124. Levidow, L. European transitions towards a corporate-environmental food regime: Agroecological incorporation or contestation? J. Rural Stud. 2015, 40, 76-89. [CrossRef]

125. Allen, P.; Guthman, J. From "old school" to "farm-to-school": Neoliberalization from the ground up. Agric. Hum. Values 2006, 23, 401-415. [CrossRef]

126. Fairbairn, M. Framing transformation: The counter-hegemonic potential of food sovereignty in the US context. Agric. Hum. Values 2012, 29, 217-230. [CrossRef]

127. Allen, P. Reweaving the food security safety net: Mediating entitlement and entrepreneurship. Agric. Hum. Values 1999, 16, 117-129. [CrossRef] 
128. Allen, P.; FitzSimmons, M.; Goodman, M.; Warner, K. Shifting plates in the agrifood landscape: The tectonics of alternative agrifood initiatives in California. J. Rural Stud. 2003, 19, 61-75. [CrossRef]

129. Dupuis, E.M.; Goodman, D. Should We Go 'Home' To Eat? Toward a Reflexive Politics of Localism. J. Rural Stud. 2005, 21, 359-371. [CrossRef]

130. Ghosh, J. The Unnatural Coupling: Food and Global Finance. J. Agrar. Chang. 2010, 10, 72-86. [CrossRef]

131. Khor, M. Intellectual Property, Biodiversity, and Sustainable Development: Resolving the Difficult Issues; Zed Books: London, UK; Third World Network: Penang, Malaysia, 2002.

132. Vivero-Pol, J.L.; Schuftan, C. No right to food and nutrition in the SDGs: Mistake or success? BMJ Glob. Health 2016, 1, e000040. [CrossRef]

133. Maskus, K.E.; Reichman, J.H. The globalization of private knowledge goods and the privatization of global public goods. In International Public Goods and Transfer of Technology under a Globalized Intellectual Property Regime; Maskus, K.E., Reichman, J.H., Eds.; Cambridge University Press: Cambridge, UK, 2005; pp. 3-45.

134. Timmer, P. Managing Price Volatility: Approaches at the Global, National, and Household Levels. Stanford Symposium Series on Global Food Policy and Food Security in the 21st Century. 2011. Available online: http://fse.fsi.stanford.edu/publications/managing_price_volatility_approaches_at_the_ global_national_and_household_levels (accessed on 15 March 2017).

135. Von Braun, J.; Birner, R. Designing Global Governance for Agricultural Development and Food and Nutrition Security. Rev. Dev. Econ. 2011. [CrossRef]

136. Vivero-Pol, J.L. The idea of food as commons or commodity in the academia. A systematic review of English scholarly texts. J. Rural Stud. 2017, in press.

137. Dalla Costa, M.R. Food as common and community. Commoner 2007, 12, 129-137.

138. Rundgren, G. Food: From commodity to commons. J. Agric. Environ. Ethics 2016, 29, 103-121. [CrossRef]

139. Foucault, M. Discipline and Punish: The Birth of the Prison; Random House: New York, NY, USA, 1975.

140. Jarosz, L. Understanding agri-food networks as social relations. Agric. Hum. Values 2000, 17, $279-283$. [CrossRef]

141. Waterman, P. Social Movements, Local Places and Globalized Spaces: Implications for 'Globalization from Below'. In Globalization and the Politics of Resistance; Gills, B.K., Ed.; Macmillan: London, UK, 2000; pp. 135-149.

(C) 2017 by the author. Licensee MDPI, Basel, Switzerland. This article is an open access article distributed under the terms and conditions of the Creative Commons Attribution (CC BY) license (http:/ / creativecommons.org/licenses/by/4.0/). 